\title{
Application of Sanctions Against State Administrative Officials Failing to Implement Administrative Court Decisions
}

\author{
Hendry Julian Noor ${ }^{\mathrm{a}, 1, *}$, Kardiansyah Afkar ${ }^{\mathrm{a}, 2}$, Henning Glaser ${ }^{\mathrm{b}, 3}$ \\ ${ }^{a}$ Faculty of Law, Universitas Gadjah Mada, Yogyakarta, Indonesia \\ ${ }^{b}$ Faculty of Law, Thammasat University, Bangkok, Thailand \\ ${ }^{1}$ hendryjuliannoor@mail.ugm.ac.id *, ${ }^{2}$ kardiansyahafkar@ymail.com, ${ }^{3}$ glasercontact@cpg-online.de \\ * corresponding author
}

\section{ARTICLE INFO}

Article history

Received: March 28, 2021

Revised: June 26, 2021

Accepted: July 10, 2021

Keywords

Administrative Sanctions

Administrative Court

Prosecutor's Office

\begin{abstract}
In its constitution, Indonesia declares itself a state of law. However, government practice frequently ignores the State Administrative Court's judgements, despite the fact that court decisions are a crucial part of the state of law notion. The purpose of this research is to determine the nature, types, and execution of administrative court decisions, as well as the position of the Prosecutor's office in the Indonesian legal system. This research also examines the legal consequences for officials that do not comply with administrative court decisions. This is prescriptive and descriptive normative legal research, comprising a statute and case approach, with data collected from primary and secondary legal materials. The result of this study shows, Firstly, the results showed that the nature of administrative court decisions is erga omnes. Secondly, the position of the Prosecutor is categorized into executive power. Thirdly, state administrative officials are obliged to implement administrative court decisions. To not implementing the administrative court decision is a violation of the principle of legality. Legal consequences for government officials that do not subject to and are disobedient to the administrative court decision with legal force should still be imposed administrative sanctions by their superiors.
\end{abstract}

aris

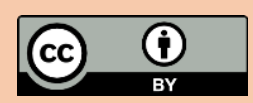

\section{Introduction}

The presence of administrative courts (Peradilan Tata Usaha Negara (PTUN)) is inseparable from its primary purpose of supervising government functionaries, thereby preventing them from abusing their positions. Supervision of these abuses is related to and continues to develop with the concept of limited government power (Wagenaar, 2004). The idea of state administrative court was established from the thoughts of F. J. Stahl associated with rechtsstaat elements. Historically, France is the first country to have an administrative court. According to Hadjon, Conseil d'etat is the pinnacle of state administrative court in France with a long historical process of transferring and adding various functions (Koskimaa et al., 2021). 
The establishment of the state administrative court is to oppose state absolutism. In the Indonesian context, the people and the government are bound by the principle of harmony by cooperating to realize the ideals of state living (Wibowo et al., 2018). However, the possibility of a dispute still exists between the people and the government. Therefore, the presence of an administrative court is still essential. One of the fundamental problems faced since the inception of the Administrative Court in 1999 is the inability of the state administrative officials to implement its decisions that are permanent and binding. Bagir Manan stated that although many decisions of the state administrative court have obtained legal force, they are still not implemented by the state administrative officials concerned. Therefore, apart from disturbing the interested parties, such actions also add a gray stamp to administrative courts, which are often considered barren, ineffective, and authoritative (Herman \& Noor, 2017).

This research aims to determine the inability of state administrative officials to implement administrative court decisions. One of the administrative court judges, Istiwibowo, stated that from 2013 to 2019 , recorded only 15 decisions were implemented from 276 administrative courts. It means that 261 other decisions, or equivalent to $95 \%$ of the decisions, were not implemented. One of the compelling cases at the national level is the dismissal of Chuck Suryosumpeno as Head of the Maluku High Prosecutor's Office based on the Decree of the Indonesian Attorney General Number Kep186/A/JA/11/2015. This was in conjunction with a Letter of the Deputy Attorney General for Supervision Number R-1154/H/Hk.1/11/2015 on the Imposition of Severe Disciplinary Punishment in connection Chuck's position as the Head of the Satgassus (Special Task Force) for the Settlement of Seizure and Confiscated Property of the Prosecutor's Office Execution from 2011—2013. The dismissal letter was sued at the Jakarta State Administrative Court, with case register Number 256/G/2015/PTUN-JKT. However, the Panel of Judges rejected Chuck Suryosumpeno's lawsuit, which the Jakarta Administrative Court appeal court strengthened (State Administrative High Court Decision No. 259/B/2016/PT.TUN.JKT of November 11, 2016), and the panel of judges at the Supreme Court (MA) through the Cassation Decision Number 156 K/TUN/2017 dated April 4, 2017 (Rumadan, 2012).

Based on the Novum, Chuck Suryosumpeno then made extraordinary legal efforts in the form of a judicial review (Peninjauan Kembali (PK)). A judicial review is defined as an extraordinary legal effort for a person to make a legal effort to resist a decision that has gained permanent legal force. There are at least a few reasons that serve as the causes for the submission, such as a) a new circumstance, b) a decision that is proven to have contradicted each other, c) an erroneously manifest, and d) if in a decision there is an act that is alleged to have been proven, but not followed by a sanction and/or criminalization yet. The Novum proved that Chuck Suryosumpeno did not make personal decisions as the head of the Satgassus in reconciliation with Taufik Hidayat's heir (Wong Tau Feng), but had agreed with the leadership, namely Attorney General, Basrief Arief. The Supreme Court through the Decision on Judicial Review Number 63 PK/TUN/2018 dated 17 May 2018 stated that the dismissal letter was invalid and the Attorney General had to rehabilitate the dignity, position, rights, and obligations related to the position of Chuck Suryosumpeno as Head of Maluku High Prosecutor's Office (Ruysschaert \& Hufty, 2020).

Factually, the judicial review (PK) decisions with legal force have never been implemented. Therefore, the Indonesian Attorney General ignored the PK decision and did not rehabilitate the dignity and position of Chuck Suryosumpeno. This also shows that state administrative officials often do not heed or comply with decisions in the state administrative court regime. Court decisions are still clearly legal in concrete cases (Gössling, 2017). Therefore, it is very important to investigate cases associated with the disobedience of decision of the administrative court carried out by the Attorney General, a high-ranking state administrative officer of the law. The Attorney General and the police are known as the initial source of a criminal justice process, they enforce the law in accordance with statutory regulations and policies established by the government (Huda et al., 2021).

Furthermore, non-compliance to law destroys the legal certainty aspired by every civilized nation. One of the manifestations is the commitment of law enforcement officials in applying rules consistently. Therefore, this allows anyone to demand the enforcement of the law with violators prosecuted and subjected to legal sanctions. Due to the importance of compliance from officials and/or state administrative agencies, Umar Dani, as a judge of the administrative court, prior to the enactment of Law Number 30 of 2014 concerning Government Administration, has proposed that administrative 
sanctions be given as a "coercive element" of officials and/or state administrative agencies to carry out each of their obligations (Dani, no year: 13), including implementing the decision of the administrative court (Huda et al., 2021).

This research is important to do because the Attorney General is the supreme leader of one of the highest institutions of the country, The Attorney General's Office, an institution that has the main duties and functions in the field of law enforcement. Based on the observations, the above case is the only case in which the supreme leader of a high institution of the state does not comply with the administrative court decision (Rukundo, 2019). Thus, if law enforcement agencies do not obey the law and do not carry out the decisions that are part of the "law", how will the law be respected and obeyed by the people? Meanwhile, in law there is lex est ratio summa, quae jubet quae sunt utilia et necessaria, et contraria prohibit, law is the highest form of reason, which commands what is useful and necessary and forbids the contrary. This research aims to keep Indonesia as a state based on the rule of law (Article 1 section (3) of 1945 Constitution) in compliance with the principles inherent in the concept of the law state (Handayani et al., 2019).

This research will begin first by explains the decisions of the administrative court. It is important to explain by considering the importance of the administrative court and legal products of the administrative court in the Indonesian legal system. Based on the fact that the a quo research departs from the disobedience of the Attorney General's Office to the administrative court decision, on the other hand, the Attorney General's Office is one of the law enforcement agencies, then it is also important to explain the position of the Prosecutor's Office in the Indonesian legal system (Goldstein, 1960). Therefore, the a quo research will explain the obligations of the officials and/or administrative agencies to the administrative court decision, in this case including the obligation for the Attorney General, as well as legal consequences for disobedience to the decision (Sahide et al., 2020). The problems formulation associated with this research are what are the nature, type, and execution of the state administrative court decisions, what is the position of the Prosecutor's Office in the Indonesian legal system, and what are the legal consequences for officials that do not implement the Administrative Court decision.

\section{Research Methods}

This is prescriptive legal research and descriptive normative legal research comprising a statute and case approach. Data were obtained from the primary and secondary legal materials. In this research, the primary legal materials were the Government Administration Law, the State Administrative Court Law, the State Administrative Court Decision Number 256/G/2015/PTUN-JKT, in conjunction with the State Administrative High Court Decision No. 259/B/2016/ PT.TUN.JKT, Supreme Court Cassation Decision Number 156 K/TUN/2017, and Supreme Court Juridical Review (PK) Decision Number 63 PK/TUN/2018, respectively. Meanwhile, the secondary legal materials were in books, journals, and scientific publications related to this research.

\section{Discussion}

\subsection{State Administrative Judicial Decisions: Nature, Types, and Execution of Decisions}

The State Administrative Court in Indonesia was established on December 29, 1986, following Law Number 5 of 1986 concerning State Administrative Courts. Although this law was promulgated on December 9, 1986, its application was regulated by the Government not later than five years. The function of the State Administrative Court is based on the principle of harmonious relations between the Government and the people. According to Setiyawan and Wulandari (2019), the main idea of rechtsstaat, which Indonesia is a part of, is to recognize and protect human rights based on the principles of freedom and equality (Zhou et al., 2017).

Stated that the principle of equality brings an equal position before the law between citizens and officials as executors of government functions. This is in line with the primary objective of administrative law, which ensures that the government's authority is used within the limits of its power (intra vires). Therefore, citizens are not violated by any "deeds" carried out by the government, and their rights are maintained (Goldstein, 1960). Administrative law also recognizes the ultra vires doctrine following the standard law system. In this doctrine, all executive actions that are not 
following the underlying provisions are declared ultra vires. The legal consequences are null and void and are presumed to have never existed (Stewart, 1977).

The concept mentioned above is closely related to administrative accountability, with Indonesia qualifying as a "grandson" or "second child" of the French legal system. Besides the legality principle used to balance the privileges of the state administration in this administrative system, there is also the power to implement decisions (decision executory). This tends to create unilateral rights and obligations capable of binding third parties. The second privilege is the particular jurisdiction (privilege de jurisdiction), which is related to the position of the administrative court to adjudicate actions in a separate justice system outside the jurisdiction of ordinary courts. In the French legal system, the authority of the administrative judiciary is authorized to adjudicate the legality of state administration's actions and claims for compensation against the government by citizens (Koskimaa et al., 2021).

The administrative court decision is broadly divided into two types. Namely, the decision issued by the Court before and after the subject of the dispute is examined. A lawsuit is rejected due to the "deficiency and absence" of the plaintiff or persecutor on the trial day. Conversely, a lawsuit is accepted when granted by the Court, further determined by the judge. This process is carried out by imposing an obligation on the State Administration Agency or officially issuing the State Administrative Decision to 1) revoke The State Administrative Decision, 2) issue a new State Administrative Decision, and 3) issuing State Administrative Decision for the lawsuit based on Article 175 Law Number 11 of 2020 in conjunction with Article 53 of the Government Administration Law (Fictional Positive State Administrative Decision) (Ishak et al., 2020).

Secondly, apart from burdening the obligations above, judges also charge for compensation and rehabilitation in employment disputes. Furthermore, after a lawsuit has been decided and declared accepted, the administrative court decision is implemented, which is part of the process in a case or dispute settlement that is part of the final or closing stage of the entire series (Noor et al., 2021). In principle, the execution of a court decision is a series of procedural processes carried out against the lost party. This is a continuous act of the entire procedural law process. In the Administrative Court context, the decision is intended as a form of modernization with a New Approach, used to solve legal problems and conflicts that occur in real life (Imam et al., 2019).

Execution is an inseparable unity from the implementation of the procedural order. The decision is mandated on the party that loses a case and is unwilling to voluntarily fulfill or carry out the court's decision. However, it is unnecessary when the lost party is ready to satisfy a court decision with legal force freely. When the missing party is the defendant, their position in the execution process becomes "the executed party." Meanwhile, assuming the disappeared party is the plaintiff, no decision needs to be executed. This is following the nature of the dispute and the status of the parties in a case. The decision execution is seen from several perspectives plaintiff's perspective in the execution and fulfillment of the things demanded in a lawsuit (petitum), the judiciary's perspective, implementation of the decision injunction or dictum taken and pronounced by a judge in a trial, which is open to the public, defendant's perspective and the execution of the decision of the Court, which is a means of enforcing the law against non-compliance of Defendant in obeying the injunction or mandate of the decision voluntarily, and the aspect of norm theory (Huda et al., 2021).

The implementation of concrete norms created by the judiciary for a case is carried out with a specific object and subject, especially the parties in the dispute. The execution is the embodiment or manifestation of an administrative court decision with permanent legal force. However, the question generally asked is associated with the meaning of administrative court decisions with unlimited legal power (inkracht van gewijsde). This is interpreted as a decision that is no longer available for ordinary legal remedies, with the dispute accepted by the decision (Dirckinck-Holmfeld, 2015).

The criteria of decision are made following the following conditions or circumstances. Firstly, a court decision is well accepted by the parties as referred to in Article 130 of Administrative Court Law. Secondly, the parties that have a dispute do not file an appeal against the court's legal decision until a grace period of 14 calendar days after notification (Article 123 of the Government Administration Law). Thirdly, the first instance court decisions in public information disputes are correctly received by the parties in a conflict. Fourthly, the court decisions at the appellate level are correctly received by the parties in the debate. Fifthly, the parties do not file an appeal against the 
court decision until a grace period of 14 days after notification regarding the contents of the mandate. Sixthly, the court decision at the appellate level is subject to the restrictions on cassation as referred to in Article 45 letter A paragraph (2) of Law Number 5 of 2004 concerning Amendments to Law Number 14 of 1985 concerning the Supreme Court. Lastly, the decision of the Indonesian Supreme Court is at the cassation level (Wagenaar, 2004).

According to Lotulung, at least two types of executions are known in the administrative court regime to recognize Administrative Court decision execution. The first is the execution of court decisions containing the obligations referred to Article 97 section (9) letter a, to revoke the State Administrative Court (beschikking). The second is the execution of the court decision containing the obligations referred to Article 97 section (9) letter b (revocation of the State Administrative decisions (beschikking) concerned and issuing new State Administrative decisions (beschikking)) and letter $\mathrm{c}$ (issuance of State Administrative Decisions (beschikking) in the lawsuit based on Article 3 of the Administrative Court Law) (Zhou et al., 2017). Furthermore, Lotulung also explained that in the first type of execution, Article 116 section (2) is applied four months after the court decision, which has obtained permanent legal force as referred to in paragraph (1) was sent. When the defendant fails to carry out assigned obligations, then the disputed State Administrative Decisions (beschikking) has no legal force anymore (Habibie et al., 2020).

In such a situation, there is no need for other actions by the court. However, based on these provisions, the state administrative decision (beschikking) automatically loses its legal power, and the type is often referred to as automatic execution (Faiz, 2016). The nature of the administrative court decision is erga omnes and binding to internal and external parties (Ibid, 40). This is the basis for "superiors" in exercising their authority to impose sanctions on the government and state administrative officials. In case $a$ quo, the President as the Chief Executive or executor of legislative power acts as the Attorney General in "forcing" the implementation of the judicial review decision. Sanctions applied to tend to increase severe administrative sanctions when there is an abuse of power. This is following Article 17 of the Government Administration Law (Bogdanova, 2018).

The problem that often arises in the execution of the administrative court decisions is the difficulty for state administration officials to comply with the administrative court decisions, which already have permanent legal force voluntarily. Ideally, a sentenced state administrative official must revoke the decision letter or issues and implement another voluntarily. However, this ideal condition cannot be applied in practice because the convicted state administrative officials (defendants) failed to carry out the administrative court decision voluntarily. The function and role of the Bailiff at the administrative court are limited to delivering notification of the conclusion of the court contents to state administration officials, and there is no coercion element in carrying out the executed decision (Simanjuntak, 2018).

Failure to implement the administrative court decision leads to decreased public trust in government officials as state administrators. Therefore, the goal of realizing a clean government free from corruption, collusion, and nepotism (KKN) is challenging. Furthermore, the existence of the administrative court as a judicial control in government is biased in the Indonesian constitutional system because the decision cannot be implemented. According to the Indonesian Supreme Court (2010), when the administrative court decision does not have executive power, the law, and society, in general, are unable to oversee the running of the government carried out by state administration officials (Effendi, 2018).

The problem of non-compliance of state administrative agencies and officials in implementing the court decisions was also analyzed by Supandi. It was stated that there were still commonplace decisions of the State Administrative Court concerned, causing legal uncertainty in the implementation of governance and development. The conclusions of Supandi's research are as follows:

"Although the State Administrative Court decisions as a juridical control institution are obeyed, the majority is broadly not obeyed. Hence, they are less effective. This is because there is no sanction agency for officials that do not implement these decisions. The position carried by public officials is a mandate from the people as the original owner of power. Nevertheless, in exercising authority, there is no legal and moral accountable mandate. Conversely, the officials misinterpret the state administrative court with the decision only 
seen from the "lose-win" aspect, excluding the "straightening" of the official decision through a state administrative court. Due to the non-compliance of state administrative officials against the practice of enforcing the law executed by the law through forced efforts in the form of payments and administrative sanctions of non-compliance in the mass media occur. The solution taken to eliminate the non-compliance of the state apparatus is made to make effective decision execution which is condemnatory to state administrative officials (defendants) by the court as an effort of a juridical control mechanism. In contrast, the maximum administrative sanctions are applied in the form of position dismissal for the sake of the state consistency as the rule of law."

According to Supandi, several decisions showed the non-compliance of State Administration officials to implement the court decision with permanent legal force. First, the conclusion of the Medan Administrative Court No. 75/G/1995/PTUN.MDN dated 6 June 1996 in conjunction with Medan State Administrative High Court No.63/Bdg.G-MD/PTTUN.MDN/ 1996 in conjunction with the Supreme Court Decision No.73K/TUN/ 1997 and the decision on judicial review by Indonesian Supreme Court No. 19/PK/TUN/1999. The decision was rendered ineffective because of the civil verdict of the Rantau District Court No. 24/Pdt.G/1995/PN.Rap in conjunction with Medan District Court No. 32/PDT/ 1997/PT.Rap, the Supreme Court Decision No. 378 K/Pdt/1998 and the decision on judicial review by Indonesian Supreme Court No. 232 PK/Pdt/2003. The administrative court decision was not implemented because it was considered contrary to a civil verdict. However, these decisions do not contradict one another. This decision relates to the cancellation of the HGU (Cultivation Rights) certificate on behalf of PT Cipta Jaya Raya Corp by the Head of the Labuhan Batu Land Office. According to Supandi (2016), this certificate was considered a procedural and substantive juridical defect (Simanjuntak, 2014).

Second, the case of drg, Yamita Br. Ginting against the Karo Regent regarding the issuance of a Decree on the dismissal and appointment of the Head of the Karo Health Office. The dismissal was met with opposition from drg. Yamita Br. Ginting by filing and winning a lawsuit with the case register No. 81/G/ 2002/ PTUN.Medan. After the panel of judges had examined and studied the case and its urgency in accordance with the provisions of Article 67 of Law Number 5 of 1986, the head of Administrative Court Medan issued a decision containing an order for the Karo Regent to suspend the implementation of the dismissal decision letter. However, at the same time, the Karo Regent issued a new decision letter with the same substance which was immediately implemented. The Karo Regent was disobedient in carrying out the State Administrative decision (Simanjuntak, 2018).

Third, the case of dualism management of the Golongan Karya Party (Golkar Party) and the Persatuan Pembangunan Party (PPP). The dualism of management of the Golkar Party occurred between the fortress of Aburizal Bakrie and the fortress of Agung Laksono. Meanwhile, dualism in the internal of PPP occurred between Rommy Rohurmusyi and Djan Farids. One of the fortresses of those parties filed a lawsuit to the Administrative Court against the ratification decree issued by Yasonna H. Laoly, the Minister of Law and Human Rights of the Republic of Indonesia. The decisions being sued are the Decree of the Minister of Law and Human Rights of the Republic of Indonesia Number M.HH-01.AH.11.01 Year 2015 on Ratification of Amendments to the Articles of Association, Bylaws, and Composition and Personnel of the Central Leadership Council of the Golongan Karya Party (March 23, 2015) and Decree of the Minister of Law and Human Rights of the Republic of Indonesia Number M.HH-06.AH.11.01 Year 2016 on Ratification of Personnel Structure of Central Leadership Council of the Persatuan Pembangunan Party 2016-2021 (April 27, 2016). Both lawsuits were granted and have had a permanent legal force up to the level of cassation in the Supreme Court, where both rulings are registered with Number 490K/TUN/2015 for management of Golkar Party cases and Decree Number 610/TUN/2015 for management of PPP cases. However, the Minister of Law and Human Rights did not carry out the executions of the two decisions (Toumbourou, 2020).

Fourth, the case of the issuance of environmental permits for cement raw material mining in Rembang Regency, Central Java. The Decree of Semarang Administrative Court Number 04/G/2009/PTUN-SMG dated August 6, 2009, granted the application of Wahana Lingkungan Hidup Foundation, by canceling the Decree of the State Administrative Official on Environmental Permits 
for Raw Material Mining Activities and the Construction and Operation of PT Semen Indonesia Tbk. The Decree of Semarang Administrative Court requires the State Administrative Official to revoke its Decree. At the appeal level, the Panel of Judges of Surabaya Administrative Court in the Decree Number 138/B/2009/PTTUN.SBY dated November 30, 2009, canceled the Decree of Semarang Administrative Court. However, at the cassation level, the Supreme Court granted the request of Walhi Foundation and overturned the Decree of Surabaya Administrative Court Number 138/B/2009/PTTUN.SBY. (Brata, Yos, Aju, 2019: 1782-1784). This is further reinforced by the Decree of the Judicial Review of Supreme Court Number 99 PK/TUN/2016 dated October 5, 2016. However, non-compliance of the Decree of Administrative Court that has been in legal force has still occurred because on January 16, 2017, the Governor of Central Java issued Decree Number 6601/4 Year 2017, which automatically revoked the Decree of the Governor Number 660.1/30 Year 2016 on Environmental Permits for Raw Material Mining Activities and the Construction and Operation of PT Semen Indonesia Tbk. Isnur, a public lawyer of YLBHI, argued that the Decree of the Judicial Review of Supreme Court Number 99/PK/TUN/2016 should be obeyed in its entirety, include by to not making a new permit that addendum to the old permit because the Supreme Court has annulled the substantive matter of the permit (Kompas.com, 2017).

Fifth, which was based on observations, is the case of former Prosecutor dismissal, Chuck Suryosumpeno, with case register No. 256/G/2015/PTUN-JKT in conjunction with State Administrative High Court Decision No. 259/B/2016/PT.TUN.JKT and with Supreme Court Cassation Decision Number 156 K/TUN/2017 in conjunction with Supreme Court Judicial Review Decision Number 63 PK/TUN/2018. Based on the novum proposed in the judicial review, the Panel of Judges gave a consideration. When the PK Petitioner fails to decide with the heirs of Taufik Hidayat (Wong Tau Feng), after receiving a leadership's approval, namely Attorney General Basrief Arief, then the cassation decision cannot be defended and needs to be canceled. In conclusion, in dismissal cases with political implications, the attitude of state administrative officials tends to be disobedient in implementing the administrative court decision (Derks \& Romijn, 2019).

The nature of the State Administrative Procedure Law is indeed different from the Civil Procedure Law. This follows Article 119 in the Administrative Court Law, which stated that the Court Head is only reasonable to carry out a supervisory function (toezicht function). Furthermore, this is different from the Court function in Civil Procedure Law as an executor of decisions permanently obtained by legal force through the bailiff (Shah, 2015). Implementing administrative court decisions is a general legal phenomenon, which indicates that they occur in many countries. Even though various regulations and mechanisms have regulated this, there are still no forced efforts from a juridical perspective against agencies or officials concerned to comply with the contents of the Administrative Court decision (Fossati et al., 2020).

According to Case No.13/G/2009 collected from the Indonesian Supreme Court dated April 1, 2009 , there was a dispute regarding the application for an oil palm plantation location permit between PT Patiware Perintis Makmur as the Plaintiff against the Mayor of Singkawang as the Defendant. The panel of judges examining and deciding the case granted the claim of Plaintiff in its entirety, and declared Decree No. 591/044/Renc-Bappeda dated January 28, 2009, which was issued by Defendant null and void. However, the decision of the State Administrative Court was not implemented by Defendant. Therefore, based on this research, there were several problems related to the execution of the Administrative Court decision (Zhang et al., 2017). The first is the uncertain execution mechanism. There is a final settlement in the implementation of the administrative court decision which has permanent legal force when the President ignores the last resort issued by the Head of the Administrative Court. Similar problems are also faced when the execution model through the superior agency is not implemented. Secondly, a problem is raised on the subject of forced money, its nominal and source when charged to the government agency of the state administrative official. Thirdly, there is regional autonomy, for regents or mayors as state administration officials that never acknowledge themselves as subordinates of the governor (Gore, 2021).

The weak execution of administrative court decisions with legal force remains due to several factors (Jones et al., 2021). Firstly, the absence of legal rules compelling state administrative officials to implement administrative court decisions. Secondly, the factor of the decision of the judge does not explicitly include the payment of forced money assuming the state administrative official does not carry out the decision. Thirdly, the factor of compliance owned by the state administration officials is 
used to carry out the administrative court decisions with permanent legal force. The weakness of the hierarchical level pattern execution combined with the will of the defendant (self-respect) without any coercion and sanctions as regulated by Article 116 of Law Number 5 of 1986 has been abandoned by Law Number 9 of 2004 (First Amendment to Law Number 5 of 1986) using legal instruments. The instruments are forced efforts/means (dwang middelen) in the form of mandatory payment and administrative sanctions to defendants not willing to implement court decisions, which is also announced (bekendmaking) in the printed mass media (Takagi et al., 2021).

This pattern is widely recognized as associated with weaknesses, especially regarding the source of forced money and the types of administrative sanctions not regulated by Article 116 of Law Number 9 of 2004, hence the implementation is difficult. However, in its development, this weakness was improved by Law Number 51 of 2009 (Second Amendment to Law Number 5 of 1986) which adds section (7) in Article 116. This section determines the amount of forced money, type of administrative sanctions, and procedures for its implementation (Arayankalam et al., 2021). This provision is one of the driving forces for the issuance of Government Regulation Number 48 of 2016 concerning Procedures for Imposing Administrative Sanctions for Government Officials (López-Ayllón et al., 2015).

Regarding law amendments, Satjipto Rahardjo stated that written law/legislations are likely to be left behind by developments or dynamics in society. Moreover, Sudikno Mertokusumo stated that het recht hink achter de feiten aan, which means the law is always behind the events (Effendi, 2018). In the context of the Administrative Court Law, especially by analyzing the changes made in Article 116. It shows that the execution of the administrative court decision is still looking for a form or pattern (shock of the paradigm), which does not have a fixed and firm paradigm (Rumadan, 2012). In the perspective of legal philosophy, the reality of not implementing a legal rule is very likely to happen. Immanuel Kant as a follower of the rational natural law school stated that from katagorische imperatif, it is necessary to have two characteristics, namely rationality, and idealism. It is possible for human actions different from what is stated by katagorische imperatif to occur (Abrams, 2019).

\subsection{The Position of the Prosecutor's Office in the Indonesian Legal System}

The government's authority in state administrative law is given based on a positive legal provision (Herman \& Noor, 2017). Prosecutor's Office is part of the Government in expressive verbis as mentioned in Article 2 section (1) of Law Number 16 of 2004. According to Maringka (2017), it is a "government institution exercising state power in the field of prosecution". Marwan Effendy stated that the existence of Law Number 16 of 2004 concerning the Indonesian Prosecutor's Office further strengthens the position as a government institution (Effendy: 2005). Based on Article 2 of the Law on the Prosecutor's Office, Achmad Ali (2013) by quoting Marwan Effendy drew the following conclusions. Firstly, it is an instrument of the law enforcing state. Secondly, its main task is as a public prosecutor. Thirdly, the Prosecutor's Office needs to uphold human rights and state law. Fourthly, it is one and inseparable (Bogdanova, 2018).

According to Djoko Prakoso, in carrying out its functions, duties, and authorities, the Prosecutor's Office is always in touch with other agencies. Therefore, the Prosecutor's Office is included in the executive power. According to Djoko Prakoso, this law was inspired by the history of the Majapahit Kingdom, which had a Gajah Mada governor that also served as State Attorney/King Prosecutor and right-hand man that oversees the implementation of the law of The King (Suhariyanto, 2019). The three laws above reinforced and placed the position of the Attorney General as a President's Assistant (Effendy: 2005). Based on this legal fact, it was concluded that in the context of its position, the Indonesian Prosecutor's Office is not only a law enforcement (judicative) apparatus, rather it is also part of the executive power with the authority to assist in carrying out its duties and executive functions in the government (Pratama et al., 2020).

In other words, the Prosecutor's Office is organically, structurally, and functionally categorized as the executive power, which functions as a law enforcer together with court agencies under the jurisdiction of the judiciary. Therefore, the Prosecutor's Office needs to be able to maintain and uphold the government and the state authority as well as protect the interests of the people through law enforcement. Furthermore, the Prosecutor's Office needs to be able to place the government and state interests in harmony as well as balance and protect the rights and obligations of citizens as carried out in America and the Netherlands. However, in Indonesia, they have a wide and varied role and function. 
This is because the Netherlands influenced the Public Prosecutors' Office in America (sixteenth century) and Indonesia (nineteenth century). Another country that is similar in arrangement to the Prosecutor's Office in Indonesia is Thailand (Berlemann \& Christmann, 2020).

The Attorney General's position is also tied to the bureaucracy, which is also a tool of government and state power for those capable of controlling the process. Generally, officials are jointly interested in the continuity of a working system carried out systematically from top to bottom or vice versa (Farhan \& Hoebink, 2019). Each level has duties and obligations to achieve institutional goals, such as welfare, order, and security. It needs to be recognized that some views "place" the Attorney General as a position capable of qualifying as a political office, such as state officials elected by the people or representatives or appointed and dismissed by the President for carrying out its functions independently (Harjiyatni \& Suswoto, 2017).

\subsection{Legal Consequences and Sanctions for Officials failing to Implement Administrative Court Decisions}

The government's action to impose administrative sanctions is a doctrinal idea that is not normatively defined in law. H.D. van Wijk/Willem Konijnenbelt defined sanctions as "De sancties in het administratiefrecht zijn de publiekrechtelijke machtmiddelen die de overheid kan aanwenden als reactie op niet naleving van administratief-rechtelijke normen" (Administrative law sanctions are powerful tools used by the authorities). Based on van Wijk/Konijnenbelt's opinion mentioned above, the elements of administrative legal sanctions include the tools of power (machtmiddelen) which are in the public law regime (publiekrechtelijke) (Moriconi \& Moriconi, 2021).

These are given by the government/ruling agencies (overheid), reactions to non-compliance (reactie op niet naleving), and the application of administrative law norms (administratiefrechtelijke normen). Meanwhile, J.J. Oostenbrink defined administrative sanctions as "Administratief sancties zijn dus sancties, die voortspruiten uit de relatie overheid-onderdaan en die zonder tussenkomst van derden en met name zonder rechtelijke machtiging rechtstreeks door de administratie zelf kunnen worden opgelegd" (Administrative sanctions arise from the relationship between the government and citizens/subjects implemented without the intermediary of a third party such as judicial powers) (Henricks, 2021).

The principle of applying administrative sanctions is to correct deviations from obligations and prohibitions. It aims to have a direct impact and execution on the party that violates the rules also known as the parate executie (Lee et al., 2019). Strictly, every legal subject that commits a legal action and causes harm to other parties needs to be responsible for their action against the injured party. Related to the concept of public law, legal responsibility is closely related to the use of authority, which is then created to the main principles in the concept of the Indonesian rule of law, namely geen bevoegheid zonder verantwoordelijkheid, or there is no authority without responsibility. Every authority needs to have a legal responsibility as a consequence of that authority. However, the use of legal discovery argumentum a contrario prevents responsibility in the concept of Human Rights, assuming no authority is given or delegated (Santaularia et al., 2021).

In this context, the discourse that always becomes a question is associated with determining the legal consequence or responsibility of Government and state administration officials that lead an institution. "Coercion" or "order" to carry out the administrative court decision is mandated by Article 116 of Law Number 51 of 2009 concerning the Second Amendment to Law Number 5 of 1986 on State Administrative Courts. Section (7) stated that "Provisions regarding the amount of forced money, types, of administrative sanctions and procedures for the payment of forced money, are regulated by statutory regulations." However, until now the regulation in question has not been made by the government (Taxman et al., 1999). In the administrative court, the principle of self-respect or selfobedience applies to the decision by the government apparatus. This means that the implementation of the administrative court decision needs to be carried out in a form of appreciation from the state administrative official as an administrative state (Othman, 2006).

This condition is recognized by the Drafters of the Government Administration Bill. However, the issuance of Law Number 30 of 2014 concerning Government Administration did not change the "legal vacuum" mandated to be filled in by Article 116 paragraph (7) of the State Administrative Law as previously described. However, the Government Administration Law indirectly anticipates that when the administrative court decision is not implemented by the government administrative officials, the 
threat of administrative sanctions is imposed on officials that do not comply or implement the administrative court decision (Minzner, 2011).

Furthermore, the provisions of Article 116 section (2) of the Administrative Court Law is as follows: "If after 60 (sixty) working days a court decision that has obtained permanent legal force as referred to in section (1) is received by the defendants, without their obligations as referred to in Article 97 section (9) letter a, becomes legally enforceable." This provision is identical to the decision in a case of material review rights (PHUM) in the Supreme Court, which has a pro future effect. It also states that assuming the state administrative agencies or officials (legislators) failed to implement the revocation of statutory provisions canceled by the PHUM decision within 90 days, then the provisions of the legislation in question do not have binding legal force (See Article 8 paragraph (2) of Supreme Court Regulations No. 1 of 2011).

Government Administration Law is a legal instrument aimed at administrators, while the Administrative Court Law is the basis for the enforcement of material of administrative law that adheres to the view that the judiciary through the head of the court has the duty and responsibility to ensure obedience. Article 72 section (1) of the Government Administration Law stated that: "Government Agencies and Officials are obliged to implement Legitimate Decisions and Actions that have been declared invalid or canceled by the Court and relevant superior." The regulation is complemented in Article 80 section (2) of the Government Administration Law, which stated that "Government Officials responsible for violating the provisions referred to in Article 25 section (1), Article 25 section (3), Article 53 section (2), Article 53 section (6), Article 70 section (3), and Article 72 section (1) are subjects to moderate administrative sanctions. "

The construction of the two articles is linked to the provisions of Article 9 section (2) of Government Regulation Number 48 of 2016 concerning Procedures for Imposing Administrative Sanctions for Officials. This matter is regulated in Article 81 section (2) of the Government administration Law, as follows. Moderate administrative sanctions referred to in Article 80 section (2) are in the form of payment of forced money and compensation, temporary dismissal with and without obtaining office rights. One of these provisions is applied in terms of meeting those stipulated by Article 7 of Government Regulation No. 48 of 2016. This is in accordance with moderate Administrative Sanctions as referred to in Article 4 letter b imposed on Government Officials, assuming they do not carry out the following obtain approval from a superior official in accordance with the provisions of laws and regulations on the use of Discretion which has the potential to change the budget allocation, notify Supervisors officials before and after the use of Discretions if causes public unrest, emergencies, and natural disasters, stipulate and make Decisions as well as Actions within 10 (ten) working days after the complete application is received by government agencies and officials assuming the provisions of laws and regulations do not specify a time limit for obligations, determine the decision to implement the court decision not later than 5 (five) working days after it is stipulated, return money to the state treasury if a decision leads to the payment of state money that is declared invalid, and carry out legitimate decisions and actions that have been declared invalid by the court or the official concerned.

Furthermore, Article 83 of the Government administration Law is stated as follows, (1) Minor, moderate, or severe administrative sanctions are imposed by considering elements of proportionality and justice. According to section (2) moderate or severe administrative sanctions are only imposed after going through an internal examination process. This regulation is complemented by Article 84 of the Government administration Law, which stated that "Further provisions regarding the procedures for the imposition of administrative sanctions as referred to in Article 80, 81, 82, and 83 are regulated by a government". This is similar to Government Regulation No. 48 of 2016, Article 11 section (2) "Moderate or Severe Administrative Sanctions as referred to in Article 9 section (2) and (3) which is only imposed after going through an internal examination process"(Tallberg, 2002).

Therefore, the moderate and severe administrative violations include indirect sanctions. Furthermore, the violations of the provisions threatened with administrative sanctions do not need to pass through the mechanism specified in Government Regulation No. 48 of 2016, which starts with public complaints to the APIP (Government Internal Supervisory Apparatus). It was checked behind closed doors and sanctions were imposed by the officials concerned. The next provision, namely Article 28 section (2) of Government Regulation No.48 of 2016 stated that "When the government 
official suspected of committing an Administrative Violation is the head of an institution, the examination is carried out by the internal government officials of the institution" (Goldstein, 1960).

In connection with these administrative sanctions, the law was legally provided to officials that do not carry out the administrative court decision which has permanent legal force. This is because state administrative agencies and officials that do not carry out the administrative court decision are considered a form of an unlawful act, as contained in Articles 17 and 18 of Law Number 30 of 2014 concerning Government Administration. Administrative sanction is broadly divided into three types (Stewart, 1977). The first is reparative/reparatory sanctions, which are intended to restore its original condition in accordance with the law and restores it to its original state before the violation occurred. The second is punitive sanctions, which are solely aimed at punishing a person. The third is regressive sanctions, which is the revocation of rights to something decided by law as if it was returned to the actual law before the decision was taken or the violation occurred (Spencer, 2021).

Concerning this research, sanctions applied are reparative in nature, which returns something to its original state in accordance with the corridors and legal channels. Hence, the application of these sanctions as part of law enforcement carried out by the superior of state administrative agencies/officials as a manifestation of legal certainty to the spirit of court decisions as well as the authority of the government as the holder of executive power (Koskimaa et al., 2021).

One of the principles in the concept of state law is the principle of legality. Fore state administrative agencies and/or officials, the principle of legality has been expressly stipulated in Article 1 section (8) of Law Number 51 of 2009 (state administrative agency or official is a board or official that carries out government affairs based on applicable regulations of law) and Article 5 letter a of Law Number 30 of 2014 (administration in government based on: a. Principle of legality). The implementation of the administrative court decisions and sanctions for state administrative agencies/officials that do not implement the decision of PTUN is a form of realization of the principle of legality and at the same time to maintain the application of the concept of Indonesia as a law state (Wagenaar, 2004).

With the explanation above, the disobedience of the Attorney General to implement Decision on Judicial Review Number 63 PK/TUN/2018 is a violation of the principle of legality and for the sake of the law, the President should (at that time) imposes administrative sanctions to the Attorney General, as stipulated in Government Regulation Number 48 of 2016. Referring to the view of Supandi, the sanction imposed is ideally a dismissal because non-compliance is an act of "disobedience to the order of office"(Imam et al., 2019).

\section{Conclusion}

The Administrative Court decision is erga omnes, binds all internal and external parties. Types of Administrative Court decisions are those issued by the Court before the subject of the dispute is examined, and those issued when the examination of the dispute principal starts. There are two types of execution in the Administrative Court regime. The first is the execution of a court decision containing the obligation to revoke the State Administrative Court (beschikking), and the execution of a court decision containing the obligation to revoke the state administrative decisions (beschikking) in the case of a lawsuit based on a petition for negative or positive fictitious decisions. The position of the Indonesian Prosecutor's Office is organically, structurally, and functionally included in the executive power (government). It functions as an instrument of the state law enforcement (public prosecutor) and also has the authority to assist the running of executive duties. Government agencies and officials are obliged to implement the decision of the administrative court. To not implementing administrative court decisions is a violation of the principle of legality. Legal consequences for government agencies and officials that do not subject to and are disobedient to the administrative court decision that has legal force should still be imposed administrative sanctions by their superiors. Besides the non-compliance is an abuse of authority, it can also be a solution to the problem of execution of the administrative court decisions that are often seen as unenforceable. 


\section{References}

Abrams, J. (2019). The emergence of network governance in U.S. National Forest Administration: Causal factors and propositions for future research. Forest Policy and Economics, 106, 101977. https://doi.org/10.1016/j.forpol.2019.101977

Arayankalam, J., Khan, A., \& Krishnan, S. (2021). How to deal with corruption? Examining the roles of e-government maturity, government administrative effectiveness, and virtual social networks diffusion. International Journal of Information Management, 58, 102203. https://doi.org/10.1016/j.ijinfomgt.2020.102203

Berlemann, M., \& Christmann, R. (2020). Disposition time and the utilization of prior judicial decisions: Evidence from a civil law country. International Review of Law and Economics, 62, 105887. https://doi.org/10.1016/j.irle.2020.105887

Bogdanova, E. (2018). Obtaining redress for abuse of office in Russia: The Soviet legacy and the long road to administrative justice. Communist and Post-Communist Studies, 51(3), 273-284. https://doi.org/10.1016/j.postcomstud.2018.07.002

Derks, M., \& Romijn, H. (2019). Sustainable performance challenges of rural microgrids: Analysis of incentives and policy framework in Indonesia. Energy for Sustainable Development, 53, 57 70. https://doi.org/10.1016/j.esd.2019.08.003

Dirckinck-Holmfeld, K. (2015). The options of local authorities for addressing climate change and energy efficiency through environmental regulation of companies. Journal of Cleaner Production, 98, 175-184. https://doi.org/10.1016/j.jclepro.2014.12.067

Effendi, M. (2018). Peradilan Tata Usaha Negara Indonesia Suatu Pemikiran Ke Arah Perluasan Kompetensi Pasca Amandemen Kedua Undang-Undang Peradilan Tata Usaha Negara. Jurnal Hukum Dan Peradilan, 3(1), 25. https://doi.org/10.25216/jhp.3.1.2014.25-36

Faiz, P. M. (2016). The Protection of Civil and Political Rights by the Constitutional Court of Indonesia. Indonesia Law Review, 6(2), 158. https://doi.org/10.15742/ilrev.v6n2.230

Farhan, F., \& Hoebink, P. (2019). Can campaigns save forests? Critical reflections from the Tripa campaign, Aceh, Indonesia. Forest Policy and Economics, 105, 17-27. https://doi.org/10.1016/j.forpol.2019.04.012

Fossati, D., Aspinall, E., Muhtadi, B., \& Warburton, E. (2020). Ideological representation in clientelistic democracies: The Indonesian case. Electoral Studies, 63, 102111. https://doi.org/10.1016/j.electstud.2019.102111

Goldstein, J. (1960). Police Discretion Not to Invoke the Criminal Process: Low-Visibility Decisions in the Administration of Justice. The Yale Law Journal, 69(4), 543. https://doi.org/10.2307/794445

Gore, R. (2021). Ensuring the ordinary: Politics and public service in municipal primary care in India. Social Science \& Medicine, 283, 114124. https://doi.org/10.1016/j.socscimed.2021.114124

Gössling, S. (2017). 7 - Rights, Authority, and the Police. In S. Gössling (Ed.), The Psychology of the Car (pp. 139-169). Elsevier. https://doi.org/10.1016/B978-0-12-811008-9.00007-7

Habibie, M. I., Noguchi, R., Matsushita, S., \& Ahamed, T. (2020). Development of micro-level classifiers from land suitability analysis for drought-prone areas in Indonesia. Remote Sensing Applications: Society and Environment, 20(June), 100421. https://doi.org/10.1016/j.rsase.2020.100421

Handayani, I. G. A. K. R., Karjoko, L., \& Jaelani, A. K. (2019). Model Pelaksanaan Putusan Mahkamah Konstitusi yang Eksekutabilitas Dalam Pengujian Peraturan Perundang-Undangan di Indonesia. Bestuur, 7(1), 36-46. https://dx.doi.org/10.20961/bestuur.v7i1.42700 
Harjiyatni, F. R., \& Suswoto, S. (2017). Implikasi Undang-Undang Nomor 30 Tahun 2014 Tentang Administrasi Pemerintahan Terhadap Fungsi Peradilan Tata Usaha Negara. Jurnal Hukum Ius Quia Iustum, 24(4), 601-624. https://doi.org/10.20885/iustum.vol24.iss4.art5

Henricks, K. (2021). Power to the Paperwork? Mandatory Financial Sanctions and the Bureaucratic Means to Racially Unequal Ends. American Behavioral Scientist, 65(8), 1104-1126. https://doi.org/10.1177/0002764219859620

Herman, H., \& Noor, H. J. (2017). Doktrin Tindakan Hukum Administrasi Negara Membuat Keputusan (Beschikking). Jurnal Komunikasi Hukum (JKH), $3(1), 82$. https://doi.org/10.23887/jkh.v3i1.9240

Huda, N., Nur Heriyanto, D. S., \& Gani Wardhana, A. F. (2021). The urgency of the constitutional preview of law on the ratification of international treaty by the Constitutional Court in Indonesia. Heliyon, 7(9), e07886. https://doi.org/10.1016/j.heliyon.2021.e07886

Imam, M. I., Jamasb, T., \& Llorca, M. (2019). Sector reforms and institutional corruption: Evidence from electricity industry in Sub-Saharan Africa. Energy Policy, 129, 532-545. https://doi.org/10.1016/j.enpol.2019.02.043

Ishak, N., Hasibuan, R. R., \& Arbani, T. S. (2020). Bureaucratic and Political Collaboration Towards a Good Governance System. Bestuur, 8(1), 19. https://doi.org/10.20961/bestuur.v811.42922

Jones, J., Keller, P., \& van der Flier Keller, E. (2021). Review of official responsibility for the Salish Sea marine environment. Ocean and Coastal Management, 211(May), 105748. https://doi.org/10.1016/j.ocecoaman.2021.105748

Koskimaa, V., Rapeli, L., \& Hiedanpää, J. (2021). Governing through strategies: How does Finland sustain a future-oriented environmental policy for the long term? Futures, 125, 102667. https://doi.org/10.1016/j.futures.2020.102667

Lee, D., Heffron, J. L., \& Mirza, M. (2019). Content and Effectiveness of Interventions Focusing on Community Participation Poststroke: A Systematic Review. Archives of Physical Medicine and Rehabilitation, 100(11), 2179-2192.e1. https://doi.org/10.1016/j.apmr.2019.06.008

López-Ayllón, S., García, A., \& Fierro, A. E. (2015). A Comparative-Empirical analysis of administrative courts in Mexico. Mexican Law Review, 7(2), 3-35. https://doi.org/10.1016/S1870-0578(16)30001-4

Minzner, C. (2011). Judicial disciplinary systems for incorrectly decided cases: The imperial Chinese heritage lives on. Chinese Justice: Civil Dispute Resolution in Contemporary China, 63, 5890. https://doi.org/10.1017/CBO9780511977008.003

Moriconi, P. R., \& Moriconi, K. (2021). Conflito de competência entre órgãos da saúde e da agricultura na inspeção e fiscalização de açougues no Estado de São Paulo. Revista de Direito Sanitário, 21. https://doi.org/10.11606/issn.2316-9044.rdisan.2021.156112

Noor, H. J., Afkar, K., \& Glaser, H. (2021). Application of Sanctions Against State Administrative Officials in Failure to Implement Administrative Court Decisions. BESTUUR, 9(1), 72. https://doi.org/10.20961/bestuur.v9i1.49686

Othman, N. (2006). Muslim women and the challenge of Islamic fundamentalism/extremism: An overview of Southeast Asian Muslim women's struggle for human rights and gender equality. Women's Studies International Forum, 29(4), 339-353. https://doi.org/10.1016/j.wsif.2006.05.008

Pratama, I. W. D. C., Dewi, A. A. S. L., \& Suryani, L. P. (2020). Upaya Paksa terhadap Pejabat yang Tidak Melakukan Putusan Pengadilan Tata Usaha Negara Denpasar. Jurnal Preferensi Hukum, 1(2), 145-149. https://doi.org/10.22225/jph.1.2.2352.145-149 
Rukundo, S. (2019). Wikipedia in the Courts: An examination of the citation of Wikipedia in judicial opinions in Uganda. Computer Law \& Security Review, 35(5), 105316. https://doi.org/10.1016/j.clsr.2019.03.010

Rumadan, I. (2012). Problematika Eksekusi Putusan Pengadilan Tata Usaha Negara. Jurnal Hukum Dan Peradilan, 1(3), 435. https://doi.org/10.25216/jhp.1.3.2012.435-462

Ruysschaert, D., \& Hufty, M. (2020). Building an effective coalition to improve forest policy: Lessons from the coastal Tripa peat swamp rainforest, Sumatra, Indonesia. Land Use Policy, 99, 103359. https://doi.org/10.1016/j.landusepol.2018.04.034

Sahide, M. A. K., Fisher, M., Nasri, N., Dharmiasih, W., Verheijen, B., \& Maryudi, A. (2020). Anticipating a new conservation bureaucracy? Land and power in Indonesia's Essential Ecosystem Area policy. Land Use Policy, 97(June), 104789. https://doi.org/10.1016/j.landusepol.2020.104789

Santaularia, N. J., Larson, R., \& Uggen, C. (2021). Criminal punishment and violent injury in Minnesota. Injury Epidemiology, 8(1), 1-11. https://doi.org/10.1186/s40621-021-00303-3

Shah, D. (2015). The "Allah" case: Implications for religious practice and expression in Malaysia. Oxford Journal of Law and Religion, 4(1), 141-146. https://doi.org/10.1093/ojlr/rwu057

Simanjuntak, E. (2014). Prospek Ombudsman Republik Indonesia Dalam Rangka Memperkuat Pelaksanaan Eksekusi Putusan Peradilan Tata Usaha Negara. Jurnal Hukum Dan Peradilan, 3(2), 163. https://doi.org/10.25216/jhp.3.2.2014.163-176

Simanjuntak, E. (2018). Prospek Prinsip Fiktif Positif Dalam Menunjang Kemudahan Berusaha Di Indonesia. Jurnal Rechts Vinding: Media Pembinaan Hukum Nasional, 7(2), 301. https://doi.org/10.33331/rechtsvinding.v7i2.250

Spencer, D. M. (2021). Sanctuary cities and the power of the purse: An executive dole test. Iowa Law Review, 106(3), 1209-1251. https://doi.org/10.2139/ssrn.3716652

Stewart, R. B. (1977). Pyramids of Sacrifice? Problems of Federalism in Mandating State Implementation of National Environmental Policy. The Yale Law Journal, 86(6), 1196. https://doi.org/10.2307/795705

Suhariyanto, B. (2019). Urgensi Kriminalisasi Contempt of Court untuk Efektivitas Pelaksanaan Putusan Peradilan Tata Usaha Negara. Jurnal Konstitusi, 16(1), 192. https://doi.org/10.31078/jk16110

Takagi, H., Esteban, M., Mikami, T., Pratama, M. B., Valenzuela, V. P. B., \& Avelino, J. E. (2021). People's perception of land subsidence, floods, and their connection: A note based on recent surveys in a sinking coastal community in Jakarta. Ocean and Coastal Management, 211(March), 105753. https://doi.org/10.1016/j.ocecoaman.2021.105753

Tallberg, J. (2002). Paths to compliance: Enforcement, management, and the European Union. International Organization, 56(3), 609-643. https://doi.org/10.1162/002081802760199908

Taxman, F. S., Soule, D., \& Gelb, A. (1999). Graduated sanctions: Stepping into accountable systems and offenders. Prison Journal, 79(2), 182-204. https://doi.org/10.1177/0032885599079002004

Toumbourou, T. (2020). Using a Delphi approach to identify the most efficacious interventions to improve Indonesia's forest and land governance. Land Use Policy, 99, 102768. https://doi.org/10.1016/j.landusepol.2017.05.017

Wagenaar, H. (2004). "Knowing" the rules: Administrative work as practice. Public Administration Review, 64(6), 643-656. https://doi.org/10.1111/j.1540-6210.2004.00412.x

Wibowo, R. A., Yuniza, M. E., Widyaningtyas, R. S., \& Noor, H. J. (2018). Wacana Pemerintah 
Untuk Mereposisi Kelembagaan Inspektorat: Tindak Lanjut, Tanggapan, Serta Inisiasi $\begin{array}{lllll}\text { Kedepan. Jurnal Hukum \& Pembangunan, } & 716 .\end{array}$ https://doi.org/10.21143/jhp.vol48.no4.1800

Zhang, M., Rasiah, R., \& Lee, J. K. Y. (2017). Navigating a Highly Protected Market: China's Chery Automobile in Malaysia. Journal of Contemporary Asia, 47(5), 774-791. https://doi.org/10.1080/00472336.2017.1345000

Zhou, W., Peng, Y., \& Bao, H. (2017). Regular pattern of judicial decision on land acquisition and resettlement: An investigation on Zhejiang's 901 administrative litigation cases. Habitat International, 63, 79-88. https://doi.org/10.1016/j.habitatint.2017.03.013 